\title{
Laminar Organization and Age-Related Loss of Cholinergic Receptors in Temporal Neocortex of Rhesus Monkey
}

\author{
Molly V. Wagster, ${ }^{1,4}$ Peter J. Whitehouse, ${ }^{5}$ Lary C. Walker, ${ }^{1,4}$ Kenneth J. Kellar, ${ }^{6}$ and Donald L. Price ${ }^{1-4}$ \\ Departments of 'Pathology, ${ }^{2}$ Neurology, and ${ }^{3}$ Neuroscience, and the ${ }^{4}$ Neuropathology Laboratory, The Johns Hopkins \\ University School of Medicine, Baltimore, Maryland 21218, ${ }^{5}$ University Hospitals of Cleveland, Alzheimer Center, \\ Cleveland, Ohio 44106, and the ${ }^{6}$ Department of Pharmacology, Georgetown University School of Medicine, Washington, \\ D.C. 20057
}

\begin{abstract}
Using in vitro receptor autoradiography, the distributions of cholinergic muscarinic [ ${ }^{3} \mathrm{H}-\mathrm{N}$-methyl scopolamine (NMS), ${ }^{3} \mathrm{H}$ pirenzepine (PZ), and ${ }^{3} \mathrm{H}$-oxotremorine-M (OXO-M)] and nicotinic [ ${ }^{3} \mathrm{H}$-acetylcholine $\left.(\mathrm{ACh})\right]$ receptors were mapped in the temporal cortices of rhesus monkeys (Macaca mulatta) ranging from 2-22 years of age. Although high-affinity ${ }^{3} \mathrm{H}-\mathrm{PZ}$, lowaffinity ${ }^{3} \mathrm{H}-\mathrm{NMS}$ binding (M1 sites) and high-affinity ${ }^{3} \mathrm{H}-\mathrm{O}$ XOM, high-affinity ${ }^{3} \mathrm{H}-\mathrm{NMS}$ binding (M2 sites) occurred across all layers of the temporal neocortex, the laminar distribution of $M 1$ and $M 2$ receptor binding sites was different. M1 muscarinic receptor binding was concentrated in layers II and III, whereas M2 muscarinic receptor binding was greatest in layers IV and V. The concentration of both muscarinic (M1 and M2) and nicotinic receptor binding sites declined with increasing age, and decrements were uniform across all cortical layers. This investigation provides evidence for a decrease in cholinergic receptor binding with age in temporal cortices of rhesus monkeys. Moreover, these changes appear to precede previously reported age-associated memory deficits and neuropathological changes that occur in this species.
\end{abstract}

Age-related declines in cognitive function occur in humans (Horn, 1975; Osborne et al., 1982; Botwinick, 1984; Rowe and Kahn, 1987), nonhuman primates (Bartus et al., 1978; Davis, 1978; Bartus and Dean, 1979; Presty et al., 1987), and rodents (Gold and McGaugh, 1975; Goodrick, 1975; Lippa et al., 1980; Strong et al., 1980; Dean et al., 1981; Ingram et al., 1981; deToledoMorrell and Morrell, 1985). One component of such memory disorders appears to be dysfunction of cholinergic systems (Bartus et al., 1982). Some investigations of rodents have revealed significant decreases in the concentration of muscarinic receptor binding with age in the whole brain (Freund, 1980) and in the

\footnotetext{
Received Mar. 13, 1990; accepted Apr. 3, 1990.

We thank Drs. Michael D. Applegate, Linda C. Cork, Cheryl A. Kitt, Robert G. Struble, and Gary L. Wenk for helpful discussions, as well as Eleanor C. Brown Kendall A. Marcus, and Ajit Naidu for technical assistance. Tissue was kindly provided by Dr. Douglas M. Bowden of the Regional Primate Research Center, University of Washington. This work was supported by Grants NIH AG 05146, AG 03359 , and NS 20471 from the U.S. Public Health Service, as well as grants from the Alzheimer's Disease and Related Disorders Association and The Robert

L. and Clara G. Patterson Trust. D.L.P. was the recipient of Leadership and Excellence in Alzheimer's Disease (LEAD) Award NIA AG 07914 and Javits Neuroscience Investigator Award NIH NS 10580.

Correspondence should be addressed to Molly V. Wagster, Ph.D., Neuropathology Laboratory, 509 Pathology Building, The Johns Hopkins University School of Medicine, 600 North Wolfe Street, Baltimore, MD 21205-2181.

Copyright (C) 1990 Society for Neuroscience $0270-6474 / 90 / 092879-07 \$ 03.00 / 0$
}

neocortex (James and Kanungo, 1976; Waller and London, 1983; Pedigo et al., 1984; Biegon et al., 1989). However, other studies have reported no changes in the concentration of muscarinic receptor binding in cortices of aged rodents (Morin and Wasterlain, 1980; Dravid, 1983). In humans, the pattern of agerelated alterations of cholinergic receptors is uncertain. $\Lambda$ significant decrease in the concentration of muscarinic receptor binding has been shown in frontal cortices of aged humans (White et al., 1977; Perry et al., 1980). However, a study of 19 regions of the human brain found no significant differences in the concentration of muscarinic receptor binding with age in any areas (Davies and Verth, 1978). Furthermore, significant alterations in the concentration of muscarinic receptor binding were not demonstrated in temporal cortices of humans 50-97 years of age, though a trend was detected for decreased binding with age (Allen et al., 1983). More recently, a trend was demonstrated for neocortical nicotinic receptors to decrease with age in humans (Whitehouse et al.,1988).

Continuing advances in the identification of subtypes of $\mathrm{ACh}$ receptors permit the clarification of the roles of these receptor subtypes in aging and in age-related disease. Three subtypes of muscarinic cholinergic receptors have been defined based on affinities for agonists (Birdsall et al., 1978). Although it was originally believed that antagonists bound to a single muscarinic receptor, the muscarinic antagonist $\mathrm{PZ}$ has been used to define 2 subtypes of antagonist binding sites in homogenate and autoradiographic binding studies (Hammer et al., 1980). Evidence for 5 different genes coding for muscarinic receptors in humans has been shown (Bonner et al., 1987, 1988). Following Mash et al. (1985) and others, we will use "M1" to define low-affinity agonist, high-affinity PZ sites and "M2" to define high-affinity agonist, low-affinity PZ sites.

In this study, the binding of cortical muscarinic and nicotinic receptors was examined by in vitro autoradiography in temporal neocortices of rhesus monkeys 2-22 years of age. This approach has several advantages: serial sections of brains of individual animals can be processed for a variety of receptor ligands, concentrations of binding sites can be assessed by semiquantitative methods, and the distribution of ligand binding sites can be related to cortical laminae.

\section{Materials and Methods}

\section{Subjects}

Animals were grouped according to the following mean ages: Group I ( 2 years of age, $n-5$ ), Group II ( 6 years of age, $n=2$ ), Group III (13 years of age, $n=2$ ), and Group IV (20 years of age, $n=7$ ). Only 5 animals in Group IV were used for studies of ${ }^{3} \mathrm{H}-\mathrm{OXO}-\mathrm{M}$ autoradiog- 
raphy. Animals were restrained with ketamine $(10 \mathrm{mg} / \mathrm{kg}, \mathrm{i} . \mathrm{m}$.$) and$ anesthetized deeply with $\alpha$-chloralose ( $40 \mathrm{mg} / \mathrm{kg}$, i.v.), and the brains were removed. A 5-mm block was dissected from the caudal part of the left temporal lobe of each brain and frozen immediately on dry ice. Tissues were frozen $\left(-80^{\circ} \mathrm{C}\right)$ until sectioned for autoradiography. Frozen tissue was serially sectioned $(10 \mu \mathrm{m})$ on a cryostat $\left(-20^{\circ} \mathrm{C}\right)$, thaw-mounted on chrome-alum-coated glass slides, and stored $\left(-20^{\circ} \mathrm{C}\right)$ until used.

\section{Autoradiography}

High-and low-affinity muscarinic binding sites. For assessment of total binding to muscarinic receptors, slide-mounted tissue sections were incubated for $60 \mathrm{~min}$ (room temperature) in PBS ( $\mathrm{pH}, 7.4$ ) that contained 1 nм ${ }^{3} \mathrm{H}$-NMS (Wamsley et al., 1980). Adjacent sections were incubated cither in PBS with $1 \mathrm{nM}{ }^{3} \mathrm{H}-\mathrm{NMS}$ with $100 \mu \mathrm{M}$ unlabeled carbachol added to displace high-affinity agonist sites, or in PBS with $1 \mathrm{nM}{ }^{3} \mathrm{H}$-NMS plus $1 \mu \mathrm{M}$ unlabeled atropine to displace all muscarinic binding sites. All tissue sections were washed twice for $5 \mathrm{~min}$ each in ice-cold PBS to remove unbound radioactive ligand and were dipped in distilled water to remove buffer salts. Sections were dried under a stream of cool, dry air. Autoradiograms were generated by apposing sections to ${ }^{3} \mathrm{H}$-sensitive film (Ultrofilm, LKB, Sweden) in the dark for 4 weeks.

High-affinity muscarinic binding sites (M2). Slide-mounted tissue sections were incubated in $20 \mathrm{~mm}$ HEPES-Tris buffer $(\mathrm{pH}, 7.5)$ plus 10 $\mathrm{mm} \mathrm{Mg}^{2+}$ and either $1 \mathrm{~nm}{ }^{3} \mathrm{H}-\mathrm{OXO}-\mathrm{M}$ alone or $1 \mathrm{~nm}{ }^{3} \mathrm{H}-\mathrm{OXO}-\mathrm{M}$ plus $1 \mu \mathrm{M}$ atropine sulfate (Spencer et al., 1986). After the 30-min incubation $\left(30^{\circ} \mathrm{C}\right)$, slides were taken through 32 -min washes in ice-cold buffer with a final dip in distilled water. Sections were dried as described previously and stored with ${ }^{3} \mathrm{H}$-sensitive film for 12 weeks.

High-affinity muscarinic binding sites (M1). Slide-mounted sections were preincubated for 30 min $\left(25^{\circ} \mathrm{C}\right)$ in Krebs phosphate buffer $(\mathrm{pH}$, 7.4), then incubated for $60 \mathrm{~min}\left(25^{\circ} \mathrm{C}\right)$ in buffer with either $20 \mathrm{nM}{ }^{3} \mathrm{H}$ $\mathrm{PZ}$ alone or $20 \mathrm{nM}{ }^{3} \mathrm{H}-\mathrm{PZ}$ plus $1 \mu \mathrm{M}$ atropine (Yamamura et al., 1983). Slides were then washed in ice-cold buffer for $5 \mathrm{~min}$ followed by a $1-\mathrm{min}$ rinse in ice-cold distilled water. Sections were dried as described previously and stored adjacent to ${ }^{3} \mathrm{H}$-sensitive film for 3 weeks.

Nicotinic binding sites. These receptor sites were labeled by incubation with ${ }^{3} \mathrm{H}-\mathrm{ACh}$ with muscarinic receptor sites blocked by atropine (Schwartz et al., 1982). Tissues were preincubated for $10 \mathrm{~min}$ (room temperature) in $50 \mathrm{~mm}$ Tris $\mathrm{HCl}$ buffer with $120 \mathrm{mM} \mathrm{NaCl}, 5 \mathrm{mM} \mathrm{KCl}, 2 \mathrm{~mm} \mathrm{CaCl}$, and $1 \mathrm{mM} \mathrm{MgCl}(\mathrm{pH}, 7.4)$, followed by an additional $5 \mathrm{~min}$ in fresh buffer solution. This proccdure was followed by a third wash in buffer for $10 \mathrm{~min}$ (room temperature) with the addition of the cholinesterase inhibitor diisopropyl phosphorofluoridate $(100 \mu \mathrm{M})$ to prevent the hydrolysis of ACh. Slide-mounted tissue sections were then incubated (45 min) in buffer $\left(\mathrm{pH}, 7.4 ; 4^{\circ} \mathrm{C}\right)$ that contained either $6 \mathrm{nM}{ }^{3} \mathrm{H}-\mathrm{ACh}$ plus $1.5 \mu \mathrm{M}$ atropine to assess total nicotinic binding or $6 \mathrm{nM}{ }^{3} \mathrm{H}$-ACh plus $100 \mu \mathrm{M}$ carbachol and $1.5 \mu \mathrm{M}$ atropine to assess nonspecific binding. Sections of tissue were taken through a 1-min buffer wash $\left(0^{\circ} \mathrm{C}\right)$, followed by 230 -sec washes $\left(4^{\circ} \mathrm{C}\right)$ and 2 rinses in distilled water $\left(0^{\circ} \mathrm{C}\right)$. Sections were dried as described previously and apposed to ${ }^{3} \mathrm{H}$-sensitive film for 12 weeks.

\section{Analysis of autoradiograms}

Autoradiograms were quantified with a computerized image-analysis system (Loats Associates, Inc., Westminster, MD). Optical densities were converted to equivalent disintegrations $/ \mathrm{min} / \mathrm{mg}$ of methacrylate standard (auturadiographic ${ }^{3} \mathrm{H}$ microscales, Amersham, Arlington Heights, IL; Unnerstall et al., 1982). Readings were taken from the inferior bank of the superior temporal sulcus of each animal. Binding levels in cortical laminae were assessed by using the computer for the integration of structural and functional information as follows: tissue sections processed previously for autoradiography were stained with Luxol-Fast blue/Cresyl violet for the accurate visualization of cortical cytoarchitecture; images of stained sections were placed in registration with their corresponding digitized autoradiographic images on the image-analysis system; a digitized image was made of the properly oriented, stained section; and the cortical layer of interest was delineated by a cursor on the slide image and quantitated simultaneously from the same layer on the autoradiogram. No correction was made for quenching of ${ }^{3} \mathrm{H}$ ligands by myelin.

Datid on cortical layers were analyzed by a repeated measures analysis of variance (ANOVA) with age as the group factor and cortical layer as the within factor. Cholinergic receptor binding in the whole temporal cortex was analyzed by a one-way ANOVA. Post hoc analyses were performed using the Newman-Keuls test for comparisons of individual age group means. Because images were too light to lend themselves to accurate registration for measurements of cortical layers, ${ }^{3} \mathrm{H}-\mathrm{ACh}$ binding for nicotinic receptor sites was limited to analyses of only the whole temporal cortex. The dependent variable in all analyses was the concentration of receptor binding sites, expressed as $1 \times 10^{-15} \mathrm{~mol} / \mathrm{mg}$ standard.

\section{Results}

\section{Distributions of receptors in cortical laminae}

In all animals, the distributions of $\mathrm{M} 1$ and $\mathrm{M} 2$ receptor binding showed consistent variations in the laminae of temporal neocortex. Binding was significantly different among cortical layers for all muscarinic ligands examined: low-affinity ${ }^{3} \mathrm{H}-\mathrm{NMS}$ binding $(F\{5,60\}=35.44, p<0.01),{ }^{3} \mathrm{H}-\mathrm{PZ}$ binding $(F\{5,60\}=$ $51.11, p<0.01)$; high-affinity ${ }^{3} \mathrm{H}-\mathrm{NMS}$ binding $(F\{5,60\}=$ $4.57, p<0.01)$; ${ }^{3} \mathrm{H}-\mathrm{OXO}-\mathrm{M}$ binding $(F\{5,50\}=45.05, p<$ 0.01 ). M1 binding (low-affinity ${ }^{3} \mathrm{H}-\mathrm{NMS}$, high-affinity ${ }^{3} \mathrm{H}-\mathrm{PZ}$ ) was highest in layers II and III and lowest in layer VI (Fig. 1). Conversely, M2 binding (high-affinity ${ }^{3} \mathrm{H}-\mathrm{NMS}$, high-affinity ${ }^{3} \mathrm{H}-\mathrm{OXO}-\mathrm{M}$ ) was highest in layers IV and $\mathrm{V}$ and lowest in layer I (Fig. 1). ${ }^{3} \mathrm{H}-\mathrm{ACh}$ binding to nicotinic receptors was not quantified for cortical layers.

\section{Age-associated changes in receptor densities}

For all ligands examined, an age-related decline in concentrations of receptor binding was observed in temporal neocortices of rhesus monkeys. Low-affinity ${ }^{3} \mathrm{H}-\mathrm{NMS}$ binding for $\mathrm{M} 1$ receptors was reduced in the whole cortex by $32 \%$ in 20 -year-old animals as compared to 2-year-old animals $(F\{3,12\}=8.38$, $p<0.01$; Table 1, Fig. 2). ${ }^{3} \mathrm{H}-\mathrm{OXO}-\mathrm{M}$ binding for $\mathrm{M} 2$ receptors was significantly reduced with age in the whole temporal cortex $(F\{3,10\}=32.25, p<0.01$; Table 1, Fig. 2). There was a trend for reductions in ${ }^{3} \mathrm{H}-\mathrm{PZ}$ binding (for $\mathrm{M} 1$ receptors) and for highaffinity ${ }^{3} \mathrm{H}$-NMS binding (M2 receptors) with increasing age (Table 1, Fig. 2). The ${ }^{3} \mathrm{H}$-ACh binding for nicotinic receptors decreased $71 \%$ in the temporal neocortex by 6 years of age; this decrease was maintained throughout the age range studied (Table 1, Fig. 2). Significant age-by-layer interactions were not observed, except in the case of ${ }^{3} \mathrm{H}-\mathrm{OXO}-\mathrm{M}$ binding $(F\{15,50\}=$ $5.34, p<0.01)$. The difference in ${ }^{3} \mathrm{H}-\mathrm{OXO}-\mathrm{M}$ binding concentration between layers $\mathrm{V}$ and VI was greater for 2-year-old animals than for any other age group (Fig. 1). However, in general, the phenomenon of decreased muscarinic receptor binding concentration with age occurred across the temporal neocortex rather than in discrete layers.

Numerous studies of cholinergic receptors in aged rodent and primate neocortices in which nicotinic or muscarinic binding has been examined show an age-related decline in actual number of sites $\left(B_{\max }\right)$ with no change in receptor affinity $\left(K_{D}\right)$ (Strong et al., 1980; Flynn and Mash, 1986; Gurwitz et al., 1987; Kellar et al., 1987; Rinne, 1987). Although these findings lend support to the notion that the cortical cholincrgic binding concentration decreases seen with old age in these rhesus monkeys are probably decreases in $B_{\max }$, this information cannot be discerned in the current study because all receptor autoradiographic assays were performed at a single ligand concentration.

\section{Discussion}

Previous research indicates that $\mathrm{M} 1$ and $\mathrm{M} 2$ binding sites may be localized differently at the cholinergic synapse in the cerebral 
$\left[{ }^{3} H\right]$ N-METHYLSCOPOLAMINE (Low affinity)

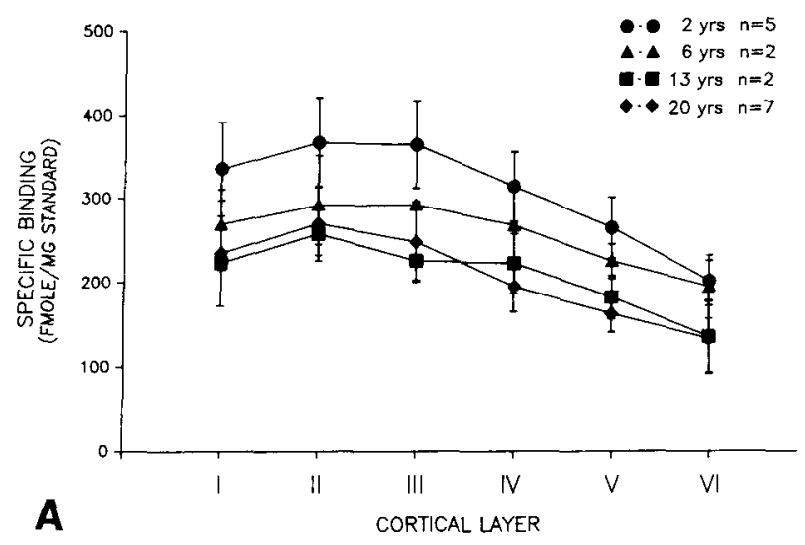

$\left[{ }^{3} H\right]$ PIRENZEPINE

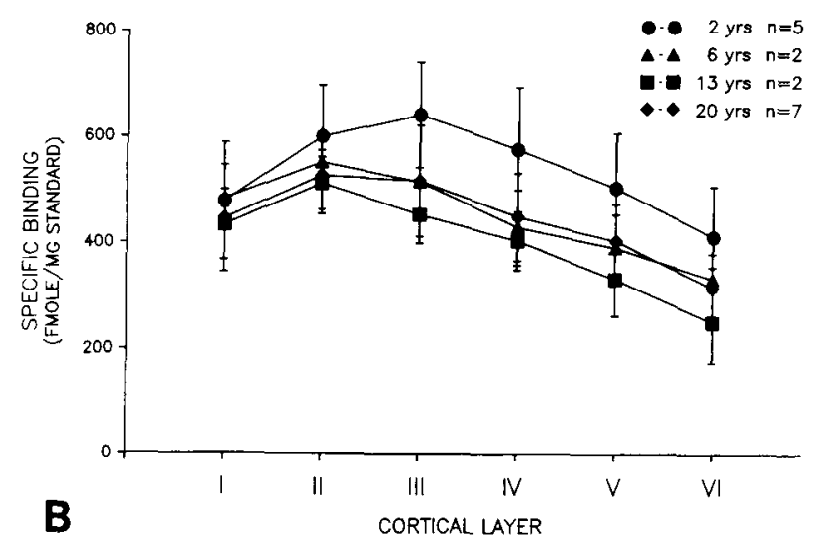

$\left[{ }^{3}\right.$ H] N-METHYLSCOPOLAMINE (High offinity)

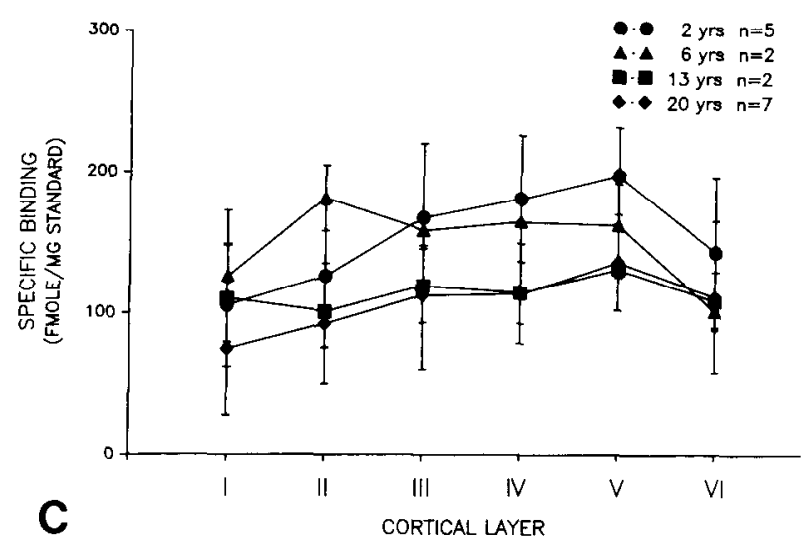

$\left[{ }^{3}\right.$ H $]$ OXOTREMORINE-M

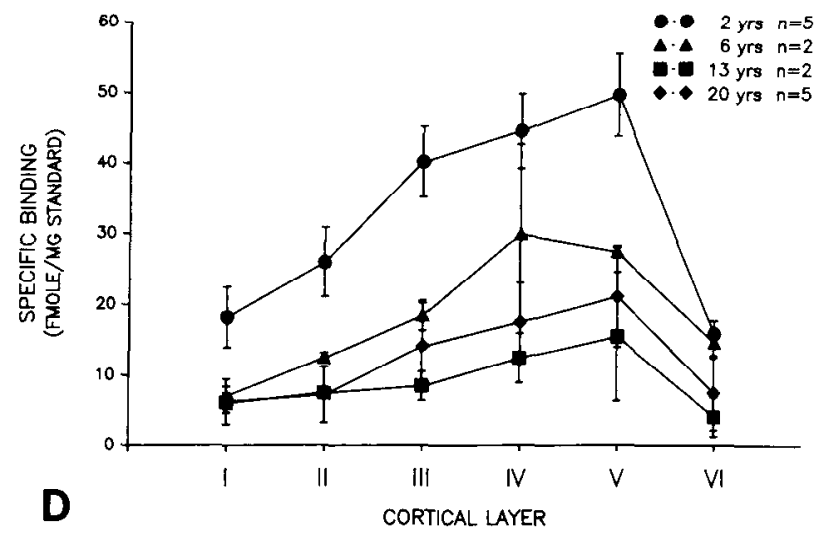

Figure 1. Laminar distribution of muscarinic receptor subtypes in temporal neocortex. Concentrations are in $1 \times 10^{-15} \mathrm{~mol} / \mathrm{mg}$ standard with standard deviation indicated on the bars. $A$ and $B$, The distribution of ligand binding for $\mathrm{M} 1$ receptor subtype. For ${ }^{3} \mathrm{H}-\mathrm{NMS}$ (low affinity) and ${ }^{3} \mathrm{H}$ $\mathrm{P} Z$, binding predominates in cortical layers II and III and follows a similar pattern for all age groups. $C$ and $D$, The distribution of ligand binding for $\mathrm{M} 2$ receptor subtype. For ${ }^{3} \mathrm{H}-\mathrm{NMS}$ (high affinity) and ${ }^{3} \mathrm{H}-\mathrm{OXO}-\mathrm{M}$, binding predominates in cortical layers IV and $\mathrm{V}$ and follows a similar pattern for all age groups.

cortex and may have different functions. M1 receptors are predominant in the neocortex (Mash et al., 1985). These receptors are not changed after lesions of the basal forebrain cholinergic system in rats (Johnston et al., 1981), nor are they reduced in corlical tissues of patients with Alzheimer's disease (Mash et al., 1985), a disorder associated with abnormalities of the basal forebrain cholinergic system and several other transmitter systems (Price, 1986). These observations suggest that M1 receptor

Table 1. Muscarinic and nicotinic receptor binding concentration in whole temporal cortex of rhesus monkey

\begin{tabular}{|c|c|c|c|c|c|c|}
\hline Group & $\begin{array}{l}\text { Mean } \\
\text { age } \\
(\mathrm{yr})\end{array}$ & $\begin{array}{l}{ }^{3} \mathrm{H}-\mathrm{NMS} \\
\text { (low affinity) }\end{array}$ & ${ }^{3} \mathrm{H}-\mathrm{PZ}$ & $\begin{array}{l}{ }^{3} \mathrm{H}-\mathrm{NMS} \\
\text { (high affinity) }\end{array}$ & ${ }^{3} \mathrm{H}-\mathrm{OXO}-\mathrm{M}$ & ${ }^{3} \mathrm{H}-\mathrm{ACh}$ \\
\hline I & 2 & $\begin{array}{l}306.00 \pm 42.42 \\
(n=5)\end{array}$ & $\begin{array}{l}564.00 \pm 94.22 \\
(n=5)\end{array}$ & $\begin{array}{l}161.00 \pm 37.17 \\
(n=5)\end{array}$ & $\begin{array}{l}37.80 \pm 4.55 \\
(n=5)\end{array}$ & $\begin{array}{l}2.63 \pm 1.31 \\
(n=5)\end{array}$ \\
\hline II & 6 & $\begin{array}{l}262.00 \pm 36.77 \\
(n=2)\end{array}$ & $\begin{array}{l}457.20 \pm 72.41 \\
(n=2)\end{array}$ & $\begin{array}{l}147.00 \pm 18.38 \\
(n=2)\end{array}$ & $\begin{array}{l}19.50^{b} \pm 2.12 \\
(n=2)\end{array}$ & $\begin{array}{l}0.75^{\circ} \pm 0.13 \\
(n=2)\end{array}$ \\
\hline III & 13 & $\begin{array}{l}225.50^{a} \pm 6.36 \\
(n=2)\end{array}$ & $\begin{array}{l}406.50 \pm 55.86 \\
(n=2)\end{array}$ & $\begin{array}{l}99.00 \pm 35.36 \\
(n=2)\end{array}$ & $\begin{array}{l}10.50^{b} \pm 4.95 \\
(n=2)\end{array}$ & $\begin{array}{l}0.79^{a} \pm 0.20 \\
(n=2)\end{array}$ \\
\hline IV & 20 & $\begin{array}{l}208.14^{a} \pm 30.06 \\
(n-7)\end{array}$ & $\begin{array}{l}458.67 \pm 69.95 \\
(n-7)\end{array}$ & $\begin{array}{l}113.14 \pm 34.90 \\
(n=7)\end{array}$ & $\begin{array}{l}14.00^{b} \pm 4.42 \\
(n=5)\end{array}$ & $\begin{array}{l}0.81^{a} \pm 0.22 \\
(n=7)\end{array}$ \\
\hline
\end{tabular}

Mean values are of specific binding expressed as $1 \times 10^{-15} \mathrm{~mol} / \mathrm{mg}$ standard $\pm \mathrm{SD}$.

${ }^{a} p<0.05$, compared to 2 -ycar-old agc group.

${ }^{b} p<0.01$, compared to 2-year-old age group. 

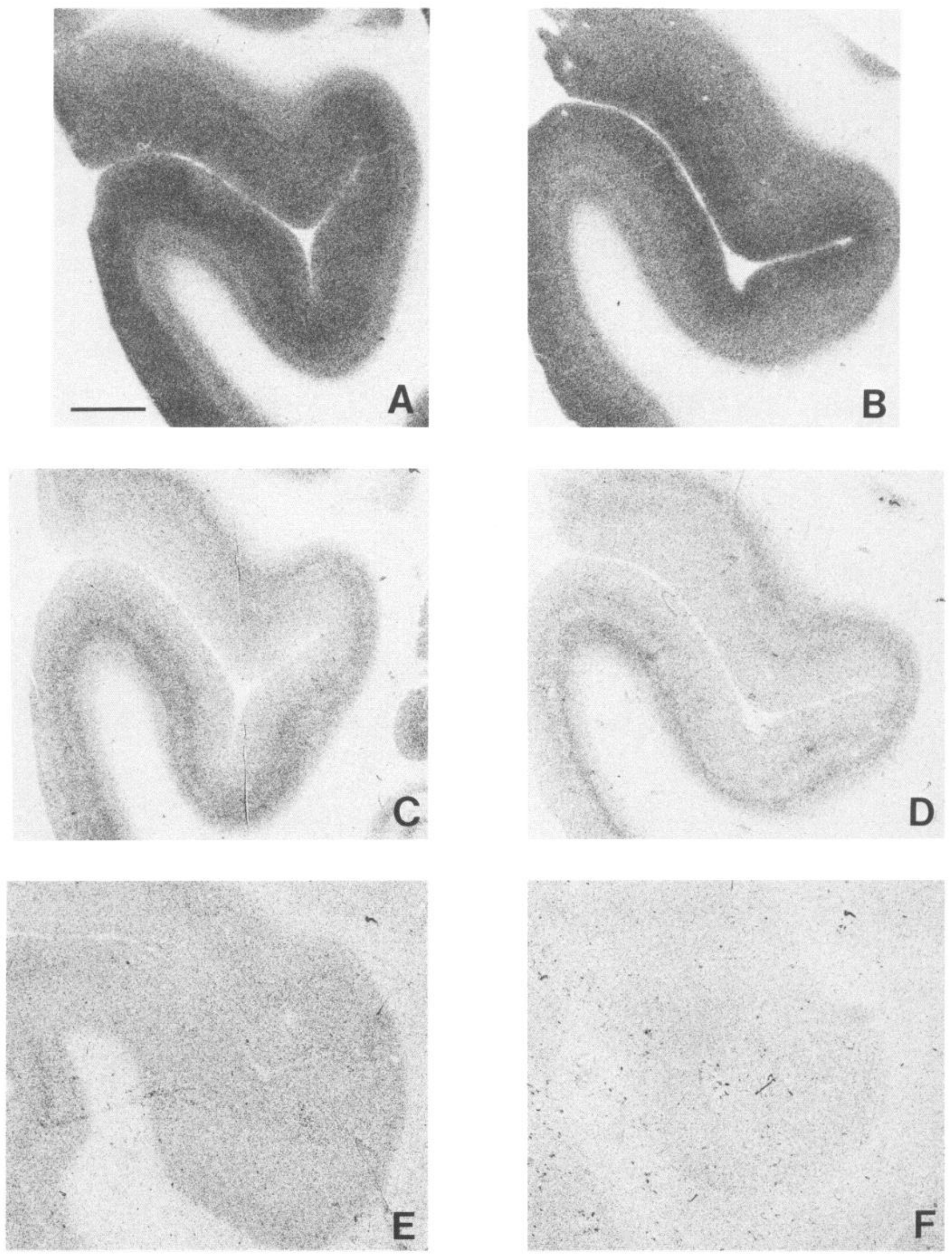
binding is postsynaptic. M2 receptors are found in cortical laminae that have the highest choline acetyltransferase (ChAT) activity (Johnston et al., 1981); in rats, lesions of the basal forebrain, which denervate the cortex, result in reductions in ChAT activity and in high-affinity agonist M2 receptors (McKinney and Coyle, 1982; Mash et al., 1985). Furthermore, M2 receptors are decreased in cerebral cortices of individuals with Alzheimer's disease (Mash et al., 1985); however, a study from our laboratory did not replicate these findings (Kellar et al., 1987). From this evidence, M2 receptors have been viewed as presynaptic autoreceptors that modulate $\mathrm{ACh}$ release from cholinergic nerve terminals (Mash et al., 1985).

Although M1 and M2 receptor binding occurred across all layers of the temporal neocortex in macaques, the present study demonstrated that $\mathrm{M} 1$ receptor binding was predominant in layers II and III, and M2 muscarinic receptor binding was concentrated in layers IV and V. The laminar pattern in macaques is consistent with studies of the distribution of M1 and M2 receptor subtypes in the human temporal cortex (Cortés et al., 1987) and rodent neocortex (Wamsley et al., 1980; Wamsley et al., 1984; Cortés and Palacios, 1986; Mash and Potter, 1986; Spencer et al., 1986). These patterns of muscarinic receptor binding show parallels with other indices of cholinergic innervation. Immunocytochemical studies demonstrate that ChATpositive axons, derived from the basal forebrain cholinergic system (Struble et al., 1986), are concentrated in layer $\mathrm{V}$ and deep layer VI of the rat cortex (Saper, 1984; Houser et al., 1985). Furthermore, ChAT-positive cell bodies, presumed to be interneurons, are concentrated in cortical layers II and III of the rat (Houser et al., 1985).

This investigation demonstrates age-related reductions in concentrations of muscarinic and nicotinic receptor binding sites in the primate neocortex. Using multiple ligands to measure a single muscarinic subtype binding site, a significant age-associated decrease was shown in low-affinity ${ }^{3} \mathrm{H}$-NMS binding for $\mathrm{M} 1$ neocortical receptors; a reduction in high-affinity ${ }^{3} \mathrm{H}-\mathrm{PZ}$ binding, labeling the same putative M1 site, did not reach statistical significance. Similarly, high-affinity ${ }^{3} \mathrm{H}-\mathrm{OXO}-\mathrm{M}$ binding for $\mathrm{M} 2$ receptors significantly decreased with age, but a change in high-affinity ${ }^{3} \mathrm{H}-\mathrm{NMS}$ binding to the same site did not reach significance. Significant age-related decreases in receptor binding and their concomitant trends are interpreted as indicative of a true age-related decrease in concentrations of cholinergic muscarinic receptor subtypes. Using ligands specific for M1, $\mathrm{M} 2$, and nicotinic cholinergic receptor subtypes, significant declines in concentrations of binding sites for both muscarinic receptor subtypes ( $\mathrm{Ml}$ and $\mathrm{M} 2$ ) were uniform across all cortical layers, and changes in cortical nicotinic receptor binding appeared to parallel this pattcrn.

ChAT, the synthetic enzyme for $\mathrm{ACh}$ and a presynaptic marker for cholinergic neurons, has been examined in aged individuals of several species. Although several researchers have reported no change in ChAT activity in whole brains and cortices of aged rodents (Meek et al., 1977; Reis et al., 1977; Ingram et al., 1981), other investigators have described a significant de- crcase in ChAT activity with age in the rodent cortex (Strong et al., 1980; Unsworth et al., 1980). Similar conflicting data concerning ChAT activity have been reported in humans. In some studies, ChAT activity declines with age in the cortex (McGeer and McGeer, 1975; Perry et al., 1977; Davies, 1978; Perry, 1980), whereas other studies have shown no change in enzyme activity (Bowen et al., 1976; Spillane et al., 1977; White et al., 1977; Carlsson et al., 1980; Yates et al., 1980). In the present study, age-related changes found in the putative presynaptic M2 receptor site and in the postsynaptic M1 receptor site correspond to reports of decreases in both cholinergic enzymes in neocortices of aged rodents and humans. Moreover, ChAT activity declines as a function of age in the rhesus monkey cortex, with statistically significant decreases occurring in the frontal pole and precentral gyrus (Wenk et al., 1989).

Although the number of animals sampled at intermediate ages was small, data suggest that there is a substantial decline in cortical muscarinic and nicotinic receptor binding concentrations between 2 and 6 years of age, with lesser reductions thereafter. Comparable information on developmental changes in muscarinic and nicotinic receptors in the human brain is not known. However, data on cholinergic enzymes is available (McGeer, 1978). Extensive studies of human postmortem tissue reveal a $78 \%$ decrease in ChAT activity in the midtemporal gyrus between 5-20 years of age. A further decrease of $71 \%$ was seen between 20-50 years of age. From the same sample, AChE levels decreased $73 \%$ between $5-20$ years of age, with an additional 54\% decrease between 20-50 years of age (McGeer, 1978). For comparison with rhesus monkey age in the present study, animal ages can be transformed into human years by multiplying by a factor of 3 . Therefore, a 2-year-old rhesus monkey would approximate, developmentally, a 6-year-old human; a 6-ycar-old rhesus monkey would approximate an 18year-old human, etc. Thus, the loss of ${ }^{3} \mathrm{H}$-cholinergic ligand binding concentration between 2- to 6-year-old rhesus monkeys in this study parallels the significant drop in cholinergic enzymes in humans of comparable age. This process may represent a normal developmental paring of receptors and certainly merits further investigation, particularly to examine the idea of a "critical" number or affinity of cholinergic receptors needed to maintain normal brain function.

Because tritiated ligands were employed in this study, one issue to be resolved is that of differential quenching of tritium by white and gray matter (Rainbow et al., 1984; Kuhar and Unnerstall, 1985). Fatty or lipid-containing tissue self-absorbs tritium, resulting in less autoradiographic optical density in white matter relative to gray matter. Are the decreases in cholinergic ligand binding with age, shown in this study, actually artifactual, due to a greater density of white matter with age? At least one report (Horrocks et al., 1975) shows that, though lipid content of the brain rises during development in humans, it stays relatively stable throughout maturity and then falls during aging. Because the neocortex is a predominantly gray matter structure, tritium quenching should have little effect on this region (Rainbow et al., 1984). Furthermore, if lipid content rises during

\footnotetext{
Figure 2. Autoradiograms of caudal temporal cortex (superior temporal sulcus) from young and old rhesus monkeys. Note the decrease with age in ${ }^{3} \mathrm{H}$ cholinergic ligand binding. Superficial layers of the temporal cortex contain high levels of ${ }^{3} \mathrm{H}-\mathrm{PZ}$ binding (M1 sites), whereas deep layers contain high levels of ${ }^{3} \mathrm{H}-\mathrm{OXO}-\mathrm{M}$ binding (M2 sites). Scale bar, $2 \mathrm{~mm}$. $A$ and $B$, The distribution of ${ }^{3} \mathrm{H}$-PZ binding sites in a 2 -year-old animal $(A)$ and a 22-year-old animal $(B)$. $C$ and $D$, The distribution of ${ }^{3} \mathrm{H}-\mathrm{OXO}$-M binding sites in a 2-year-old animal $(C)$ and a 22 -year-old animal $(D)$. $E$ and $F$, The distribution of ${ }^{3} \mathrm{H}$-ACh (nicotinic) binding sites in a 2-year-old animal $(E)$ and a 22 -year-old animal $(F)$.
} 
development, stabilizes, and then falls during aging, artifactually high optical densities would be predicted in very young animals, lower optical densities in animals of early to middle adulthond, and artifactually high optical densities in old animals. In the present study, optical densities, transformed into binding concentrations, decreased with age, providing evidence against a major role of tritium quenching in this region of primate brain.

The present study provides the first evidence for age-related changes in cholinergic receptors in the CNS of the nonhuman primate. Aged rhesus monkeys and other nonhuman primates develop some of the behavioral impairments and pathological changes that occur in aged humans, for example, senile plaques and amyloid deposits in plaques and blood vessels (Struble et al., 1982; Kitt et al., 1985; Selkoe et al., 1987; Walker et al., 1987). Studies of monkeys may provide valuable information concerning roles of the cholinergic system in cognition and memory proccssing in primates.

\section{References}

Allen SJ, Benton JS, Goodhardt MJ, Haan EA, Sims NR, Smith CCT, Spillane JA, Bowen DM, Davison AN (1983) Biochemical evidence of selective nerve cell changes in the normal ageing human and rat brain. J Neurochem 41:256-265.

Bartus RT, Dcan RL (1979) Recent memory in agcd non-human primates: hypersensitivity to visual interference during retention. Exp Aging Res 5:385-400.

Bartus RT, Fleming D, Johnson HR (1978) Aging in the rhesus monkey: debilitating effects on short-term memory. J Gerontol 33:858871.

Bartus RT, Dean RL III, Beer B, Lippa AS (1982) The cholinergic hypothesis of geriatric memory dysfunction. Science 217:408-417.

Biegon A, Hanau M, Greenberger V, Segal M (1989) Aging and brain cholinergic muscarinic receptor subtypes: an autoradiographic study in the rat. Neurobiol Aging 10:305-310.

Birdsall NJM, Burgen ASV, Hulme EC (1978) The binding of agonists to brain muscarinic receptors. Mol Pharmacol 14:723-736.

Bonner TI, Buckley NJ, Young AC, Brann MR (1987) Identification of a family of muscarinic acetylcholine receptor genes. Science 237: $527-532$

Bonner TI, Young AC, Brann MR, Buckley NJ (1988) Cloning and expression of the human and rat $\mathrm{m} 5$ muscarinic acetylcholine receptor genes. Neuron 1:403-410.

Botwinick J (1984) Aging and behavior, a comprehensive integration of research findings, $3 \mathrm{~d}$ ed. New York: Springer.

Bowen DM, Smith CCT, White P, Davison AN (1976) Senile dementia and related abiotrophies: biochemical studies on historically evaluated human postmortem specimens. In: Aging, Vol 3, Neurobiology of aging (Terry RD, Gershon S, eds), pp 361-389. New York: Raven.

Carlsson A, Adolfsson R, Aquilonius S-M, Gottfries C-G, Oreland L, Svennerholm L, Winblad B (1980) Biogenic amines in human brain in normal aging, senile dementia, and chronic alcoholism. In: Advances in biochemical psychopharmacology, Vol 23, Ergot compounds and brain function: neuroendocrine and neuropsychiatric aspects (Goldstein M, Calne DB, Leiberman A, Thorner MO, eds), pp 295-304. New York: Raven.

Cortés R, Palacios JM (1986) Muscarinic cholinergic receptor subtypes in the rat brain. I. Quantitative autoradiographic studies. Brain Res 362:227-238.

Cortés R, Probst A, Palacios JM (1987) Quantitative light microscopic autoradiographic localization of cholinergic muscarinic receptors in the human brain: forebrain. Neuroscience 20:65-107.

Davies $P$ (1978) Loss of choline acetyltransferase activity in normal aging and in senile dementia. In: Parkinson's disease. II. Aging and neuroendocrine relationships (Finch CE, Potter DE, Kenny AD, eds), pp 251-256. New York and London: Plenum.

Davies P, Verth AH (1978) Regional distribution of muscarinic acetylcholine receptor in normal and Alzheimer's-type dementia brains. Brain Res 138:385-392.

Davis RT (1978) Old monkey behavior. Exp Gerontol 13:237-250.
Dean RL III, Scozzafava J, Goas JA, Rcgan B, Bccr B, Bartus RT (1981) Age-related differences in behavior across the life span of the C57BL/ $6 \mathrm{~J}$ mouse. Exp Aging Res 7:427-451.

deToledo-Morrell L, Morrell F (1985) Electrophysiological markers of aging and memory loss in rats. Ann NY Acad Sci 444:296-311.

Dravid AR (1983) Deficits in cholinergic enzymes and muscarinic receptors in the hippocampus and striatum of senescent rats: effect of chronic Hydergine treatment. Arch Int Pharmacodyn 264:195202.

Flynn DD, Mash DC (1986) Characterization of $\mathrm{L}^{-3} \mathrm{H}-$ nicotinic binding in human cerebral cortex: comparison between Alzheimer's disease and the normal. J Neurochem 47:1948-1954.

Freund $\mathrm{G}$ (1980) Cholinergic receptor loss in brains of aging mice. Life Sci 26:371-375.

Gold PE, McGaugh JL (1975) Changes in lcarning and memory during aging. In: Advances in behavioral biology, Vol 16, Neurobiology of aging, an interdisciplinary life-span approach (Ordy JM, Brizzee KR, eds), pp 145-158. New York: Plenum.

Goodrick CL (1975) Behavioral rigidity as a mechanism for facilitation of problem solving for aged rats. J Gerontol 30:181-184.

Gurwitz D, Egozi Y, Henis YI, Kloog Y, Sokolovsky M (1987) Agonist and antagonist binding to rat brain muscarinic receptors: influence of aging. Neurobiol Aging 8:115-122.

Hammer R, Berrie CP, Birdsall NJM, Burgen ASV, Hulme EC (1980) Pirenzepine distinguishes between different subclasses of muscarinic receptors. Nature 283:90-92.

Horn JL (1975) Psychometric studies of aging and intelligence. In: Aging, Vol 2, Genesis and treatment of psychologic disorders in the elderly (Gershon S, Raskin A, eds), pp 19-43. New York: Raven.

Horrocks LA, Sun GY, D'Amato RA (1975) Changes in brain lipids during aging. In: Advances in behavioral biology, Vol 16, Neurobiology of aging, an interdisciplinary life-span approach (Ordy JM, Brizzee KR, eds), pp 359-367. New York: Plenum.

Houser CR, Crawford GD, Salvaterra PM, Vaughn JE (1985) Immunocytochemical localization of choline acetyltransferase in rat cerebral cortex: a study of cholinergic neurons and synapses. J Comp Neurol 234:17-34.

Ingram DK, London ED, Goodrick CL (1981) Age and neurochemical correlates of radial maze performance in rats. Neurobiol Aging 2:4147.

James TC, Kanungo MS (1976) Alterations in atropine sites of the brain of rats as a function of age. Biochem Biophys Res Commun $72: 170-175$.

Johnston MV, Young AC, Coyle JT (1981) Laminar distribution of cholinergic markers in neocortex: effects of lesions. J Neurosci Res 6:597-607.

Kellar KJ, Whitehouse PJ, Martino-Barrows AM, Marcus K, Price DL (1987) Muscarinic and nicotinic cholinergic binding sites in Alzheimer's disease cerebral cortex. Brain Res 436:62-68.

Kitt CA, Struble RG, Cork LC, Mobley WC, Walker LC, Joh TH, Price DL (1985) Catecholaminergic neurites in senile plaques in prefrontal cortex of aged nonhuman primates. Neuroscience 16:691-699.

Kuhar MJ, Unnerstall JR (1985) Quantitative receptor mapping by autoradiography: some current technical problems. Trends Neurosci 8:49-53.

Lippa AS, Pelham RW, Beer B, Critchett DJ, Dean RL, Bartus RT (1980) Brain cholinergic dysfunction and memory in aged rats. Neurobiol Aging 1:13-19.

Mash DC, Potter LT (1986) Autoradiographic localization of M1 and M2 muscarine receptors in the rat brain. Neuroscience 19:551-564.

Mash DC, Flynn DD, Potter LT (1985) Loss of M2 muscarine receptors in the cerebral cortex in Alzheimer's disease and experimental cholinergic denervation. Science 228:1115-1117.

McGeer EG (1978) Aging and neurotransmitter metabolism in the human brain. In: Aging. Vol 7, Alzheimer's disease: senile dementia and related disorders (Katzman R, Terry RD, Bick KL, eds), pp 427440. New York: Raven.

McGeer EG, McGeer PL (1975) Age changes in the human for some enzymes associated with metabolism of catecholamines, GABA and acetylcholine. In: Advances in behavioral biology, Vol 16, Neurobiology of aging, an interdisciplinary life-span approach (Ordy JM, Brizzee KR, eds), pp 287-305. New York: Plenum.

McKinney M, Coyle JT (1982) Regulation of neocortical muscarinic receptors: effects of drug treatment and lesions. J Neurosci 2:97-105. 
Meek LJ, Bertilsson L, Cheney DL (1977) Aging-induced changes in acetylcholine and 5-hydroxytryptamine content of discrete brain nuclei. J Gerontol 32:129-132.

Morin AM, Wasterlain CG (1980) Aging and rat brain muscarinic receptors as measured by quinuclidinyl benzilate binding. Neurochem Res 5:301-308

Osborne DP Jr, Brown ER, Randt CT (1982) Qualitative changes in memory function: aging and dementia. In: Aging, Vol 19, Alzheimer's discasc: a rcport of progress in research (Corkin S, Davis KL, Growdon JH, Usdin E, Wurtman RJ, eds), pp 165-169. New York: Raven.

Pedigo NW Jr, Minor LD, Krumrei TN (1984) Cholinergic drug effects and brain muscarinic receptor binding in aged rats. Neurobiol Aging $5: 227-233$

Perry EK (1980) The cholinergic system in old age and Alzheimer's disease. Age Ageing 9:1-8.

Perry EK, Perry RH, Gibson PH, Blessed G, Tomlinson BE (1977) A cholinergic connection between normal aging and senile dementia in the human hippocampus. Neurosci Lett 6:85-89.

Perry RH, Blessed G, Perry EK, Tomlinson BE (1980) Histochemical observations on the cholinesterase activities in the brains of elderly normal and demented (Alzheimer-type) patients. Age Ageing 9:9-16.

Presty SK, Bachevalier J, Walker LC, Struble RG, Price DL, Mishkin $M$, Cork LC (1987) Age differences in recognition memory of the rhesus monkey (Macaca mulatta). Neurobiol Aging 8:435-440.

Price DL (1986) New perspectives on Alzheimer's disease. Annu Rev Neurosci 9:489-512.

Rainbow TC, Biegon A, Berck DJ (1984) Quantitative receptor autoradiography with tritium-labeled ligands: comparison of biochemical and densitometric measurements. J Neurosci Meth 11:231-241.

Reis DJ, Ross RA, Joh TH (1977) Changes in the activity and amounts of enzymes synthesizing catecholamines and acetylcholine in brain, adrenal medulla, and sympathetic ganglia of aged rat and mouse. Brain Res 136:465-474.

Rinne JO (1987) Muscarinic and dopaminergic receptors in the aging human brain. Brain Res 404:162-168.

Rowe JW, Kahn RL (1987) Human aging: usual and successful. Science 237:143-149.

Saper CB (1984) Organization of cerebral cortical afferent systems in the rat. II. Magnocellular basal nucleus. J Comp Neurol 222:313342.

Schwartz RD, McGee R Jr, Kellar KJ (1982) Nicotinic cholinergic receptors labeled by ${ }^{3} \mathrm{H}$-acetylcholine in rat brain. Mol Pharmacol 22: $56-62$.

Selkoe DJ, Bell DS, Podlisny MB, Price DL, Cork LC (1987) Conservation of brain amyloid proteins in aged mammals and humans with Alzheimer's disease. Science 235:873-877.

Spencer DG Jr, Horváth E, Traber J (1986) Direct autoradiographic determination of M1 and M2 muscarinic acetylcholine receptor distribution in the rat brain: relation to cholinergic nuclei and projections. Brain Res 380:59-68.
Spillane JA, White P, Goodhardt MJ, Flack RHA, Bowen DM, Davison AN (1977) Selective vulnerability of neurones in organic dementia. Nature 266:558-559.

Strong R, Hicks P, Hsu L, Bartus RT, Enna SJ (1980) Age-related alterations in the rodent brain cholinergic system and behavior. Neurobiol Aging 1:59-63.

Struble RG, Cork LC, Whitehouse PJ, Price DL (1982) Cholinergic innervation in neuritic plaques. Science 216:413-415.

Struble RG, Lehmann J, Mitchell SJ, McKinney M, Price DL, Coyle JT, DeLong MR (1986) Basal forebrain neurons provide major cholinergic innervation of primate neocortex. Neurosci Lett 66:215220

Unnerstall JR, Niehoff DL, Kuhar MJ, Palacios JM (1982) Quantitative receptor autoradiography using ${ }^{3} \mathrm{H}$-ultrofilm: application to multiple benzodiazepine receptors. J Neurosci Meth 6:59-73.

Unsworth BR, Fleming LH, Caron PC (1980) Neurotransmitter enzymes in telencephalon, brain stem and cerebellum during the entire life span of the mouse. Mech Ageing Dev 13:205-217.

Walker LC, Kitt CA, Schwam E, Buckwald B, Garcia F, Sepinwall J, Price DL (1987) Senile plaques in aged squirrel monkeys. Neurobiol Aging 8:291-296.

Waller SB, London ED (1983) Age-differences in choline acetyltransferase activities and muscarinic receptor binding in brain regions of C57BL/6J mice. Exp Gerontol 18:419-425.

Wamsley JK, Zarbin MA, Birdsall NJM, Kuhar MJ (1980) Muscarinic cholinergic receptors: autoradiographic localization of high and low affinity agonist binding sites. Brain Res 200:1-12.

Wamsley JK, Zarbin MA, Kuhar MJ (1984) Distribution of high and low affinity agonist binding sites: a light microscopic autoradiographic study. Brain Res Bull 12:233-243.

Wenk GL, Pierce DJ, Struble RG, Price DL, Cork LC (1989) Agerelated changes in multiple neurotransmitter systems in the monkey brain. Neurobiol Aging 10:11-19.

White P, Goodhardt MJ, Keet JP, Hiley CR, Carrasco LH, Williams IEI, Bowen DM (1977) Neocortical cholinergic neurons in elderly people. Lancet 1:668-670.

Whitehouse PJ, Martino AM, Wagster MV, Price DL, Mayeux R, Atack JR, Kellar KJ (1988) Reductions in ${ }^{3} \mathrm{H}$-nicotinic acetylcholine binding in Alzheimer's disease and Parkinson's disease: an autoradiographic study. Neurology 38:720-723.

Yamamura HI, Wamsley JK, Deshmukh P, Roeske WR (1983) Differential light microscopic autoradiographic localization of muscarinic cholinergic receptors in the brainstem and spinal cord of the rat using ${ }^{3} \mathrm{H}$-pirenzepine. Eur J Pharmacol 91:147-149.

Yates CM, Blackburn IA, Christie JE, Glen AIM, Shering A, Simpson J, Whalley LJ, Zeisel S (1980) Clinical and biochemical studies in Alzheimer's disease. In: Biochemistry of dementia (Roberts PJ, ed), pp 185-212. New York: Wiley. 